\title{
Structural Study of Judaida Subsurface Structure, North of Iraq
}

\author{
Omar A. Naji ${ }^{1, *}$, Manal Sh. AL-Kubaisi ${ }^{2}$ and Emad A. Al-Heety ${ }^{3}$ \\ Oil Exploration Company, Iraqi Oil Ministry, Baghdad, Iraq \\ Department of Geology, College of Science, University of Baghdad, Baghdad, Iraq \\ Department of Applied Geology, College of Science, University of Anbar, Rammadi, Iraq \\ Correspondence: omargeology2@gmail.com
}

\begin{abstract}
Received:
21 September 2021

\section{Abstract}

This research focuses on the structural study of three folded horizons of Fat'ha, Jeribe, and

Accepted:

1 November 2021

Published:

31 January 2022

the Euphrates in Judaida structure, Northern Iraq. Depth contour maps for three horizons using the time and velocity data called from seismic surveys. Seismic interpretation suggests that Judaida structure is a positively inverted structure. It is an anticline on the level of Tertiary and the top and an extensional structure on the level of pre-Tertiary sequence. Judaida structure is an asymmetrical longitudinal anticline; its Northeastern limb is steeper than its Southwestern limb. The axis of the anticline and the major normal faults are both trending toward the Northwest. The normal fault picked influencing only the pre-Late Cretaceous sequence where is the folding affected the whole sequence; of the extension forces, it affected the region during that period. Late Pliocene compressions resulted in folding and reverse faulting of the whole sequence and inversion of movement along the pre-existing normal faults. The resulted faults are called inverted faults.
\end{abstract}

Keywords: 2D seismic reflection data; Structural interpretations; Judaida structure area

\section{Introduction}

This study deals with interpretation of $2 \mathrm{D}$ seismic data with well information to evaluate the structural geology of the Judaida subsurface structure. The structural maps showed that the Judaida structure is an asymmetrical longitudinal fold, characterized by structural trend and facies changes that are parallel to Zagros, Taurus belts (NW - SE) (Jassim and Goff, 2006). The study area is located within unstable shelf, at Low Folded Zone (LFZ), within Hamrin belt between the Mesopotamia Fore deep from the SW, and the High Folded Zone (HFZ) from the NE. The fold generally flattens toward the Mesopotamian basin, where a relatively narrow anticline is separated by a wide syncline (Aqrawi et al., 2010). Economically, The Jeribe Formation is a main reservoir in the region, according to the results of Jd-1 well testing. The geometry of folds gives an indicator about the degree and orientation of strain, which in turn provides critical information about the deformation history of a region (Van Der Pluijm and Marshak, 2004). This study is considered one of many studies that employed the interpretation of 2D seismic data with wells data to evaluate the subsurface structural geology in different countries (Ahmad, 2018). In Iraq (Almayahi, 2004), (Al-Ridha and Al-Khafaji, 2019) and (Abdullah et al., 2021). In Egypt (Zahra, 2016), In Pakistan (Khan, 2019). 


\section{Location of the Study Area}

The location of the study area of interest is within the administrative borders of Kirkuk district, northern Iraq. Its located $60 \mathrm{Km}$ southwestern Kirkuk Field and $35 \mathrm{Km}$ southwestern Jambor Field. The Judaida structure is bordering from the south by Hamrin Field; the Daquq River passes over the study area (Fig.1).

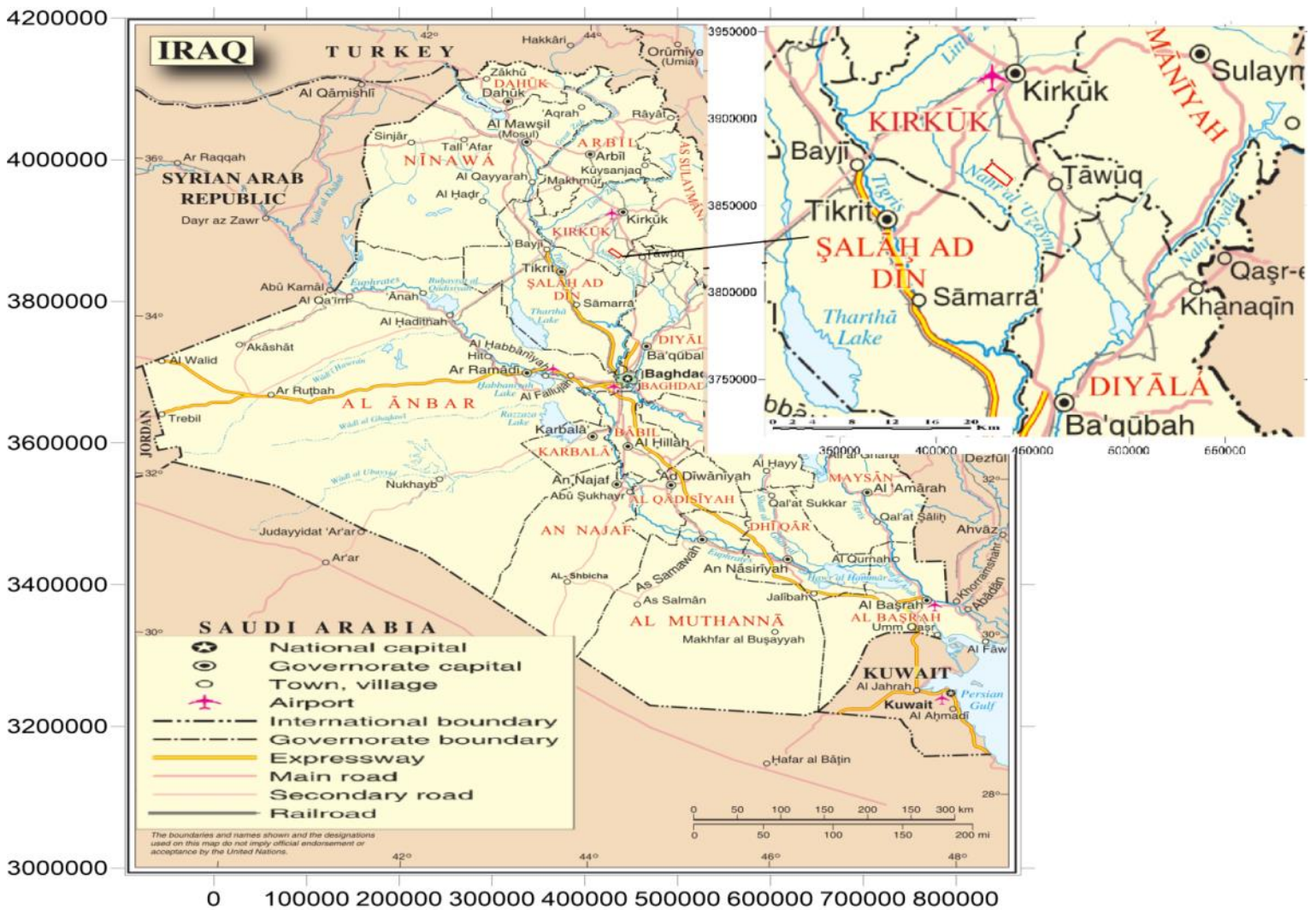

Fig.1. Location map of the study area (modified after United Nations, 2014)

\section{Tectonic of Study Area}

Tectonically, the study area is situated in the northern part of the Arabian Plate within LFZ. The tectonic map of Iraq shows that the study area lies between two fault systems (Jassim and Goff, 2006), (Fig. 2).

- Longitudinal Fault System: The area lies between two ranges of longitudinal fault systems

Kirkuk Fault

Hamrin- Makhol Fault

- Transversal Fault system: The area lies between two ranges of transversal fault system

Anah-Qalat Dizeh Fault.

Amij-Samarra Fault.

\section{Materials and Methods}

\section{1. Structural Interpretation of the Data}

The presence of faults in the area can be recognized according to the principle of faulting on reflection sections by discontinuities in reflection falling along with essentially linear pattern misclosures in tying reflection around loops (Dobrin, 1976). The study area affected by the main normal 
fault extends from the early Triassic to late Cretaceous; these faults result from extension forces that affected the area during the Cretaceous age. The fault axis direction to the Northwest-Southeast. The interpreted seismic section (Fig. 3) is divided the section into three zones:

- Zone (A) (pre-Late Campanian-Maestrichtian age).

- Zone (B) (Late-Campanian-Mestrichtian age).

- $z o n e(C)$ (post Maestrichtian age).

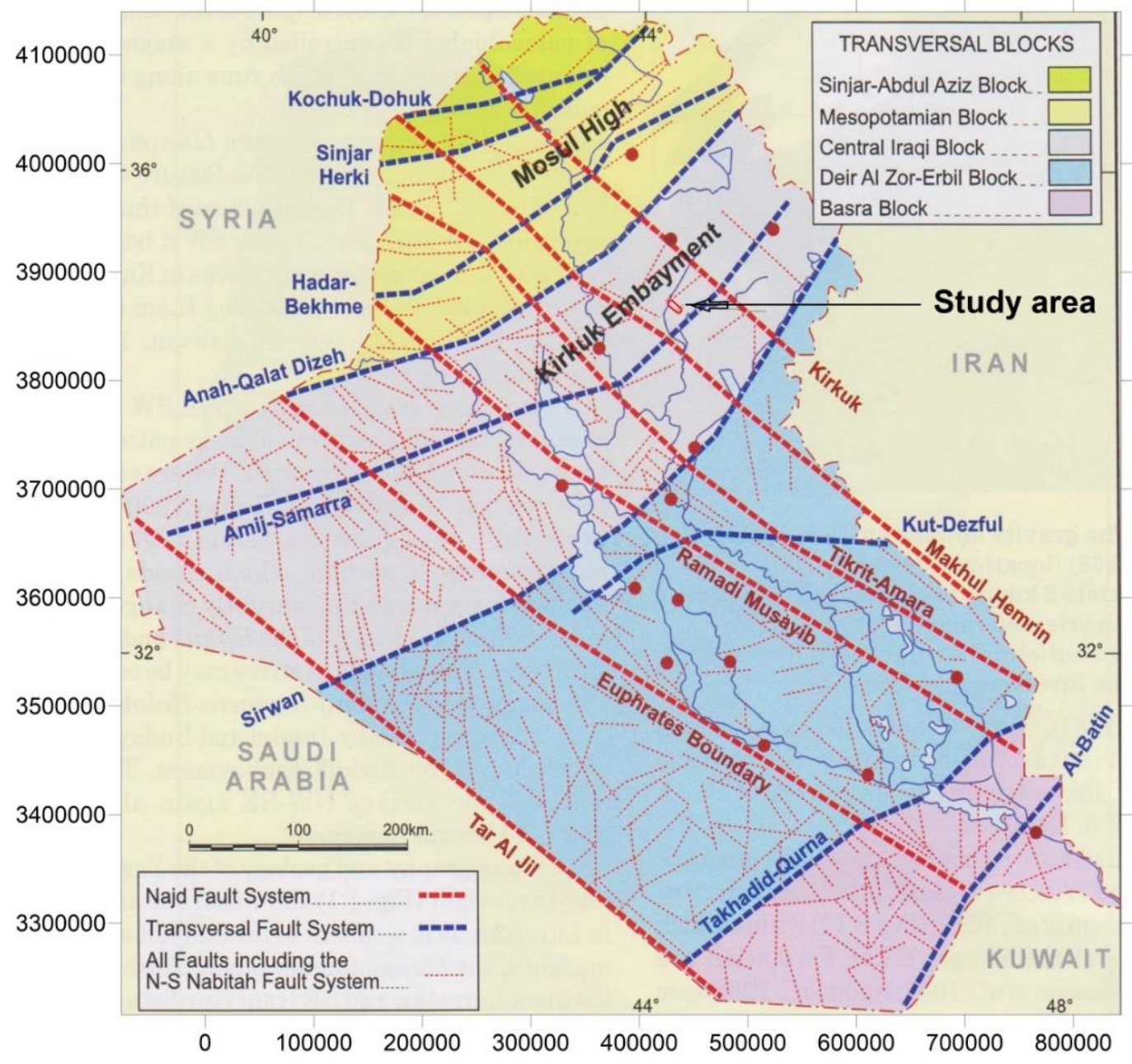

Fig. 2. Tectonic map of Iraq showing the regional fault system in the study area. (Jassim and Goff, 2006)

Its Shows zone A and zone $\mathrm{C}$ maintain approximately the same thicknesses; this is reflected by the approximate parallelism between the detailed reflectors within each zone. Zone $\mathrm{C}$ is folded, whereas zone A is folded and faulted. The same faulting is also influenced zone; B Shiranish Zone, inducing pronounced thickness variation across the major faults. The zone B is faulted and folded and suffered from fault-controlled eastward thickening. According to, this zone is considered as a synrift sequence and zone $\mathrm{A}$ is considered as a pre-rift sequence, whereas the upper zone $\mathrm{C}$ is considered as post-rift sequence. Marouf and Al Kubaisi, (2005) discussed in details similar cases from the surrounding foot Hills Subzone of Zagros simply folded belt in Northern Iraq.

The same figure shows that the Judaida structure was developed as a rift structure during the Late Campanian-Maestrichtian period. The normal faults displaced the pre-rift (Pre-late Campanian) sequence. The continuous movements along during the pre-Campanian-Mestrichtian period interval induced the thickness variations in the syn-rift Shiranish sequence. The relative tectonic quiescence in 
the post Maestrichtian time resulted into continuous relatively constant thickness deposition of Tertiary post-rift sequence. Later Pliocene (syn- Bakhtiary) compressions resulted into folding and reverse faulting of all sequence and inversion of movement along some of the pre-existing normal faults. The resulted faults are called inverted faults, and they are presented by two opposite (arrows) directions of displacements.

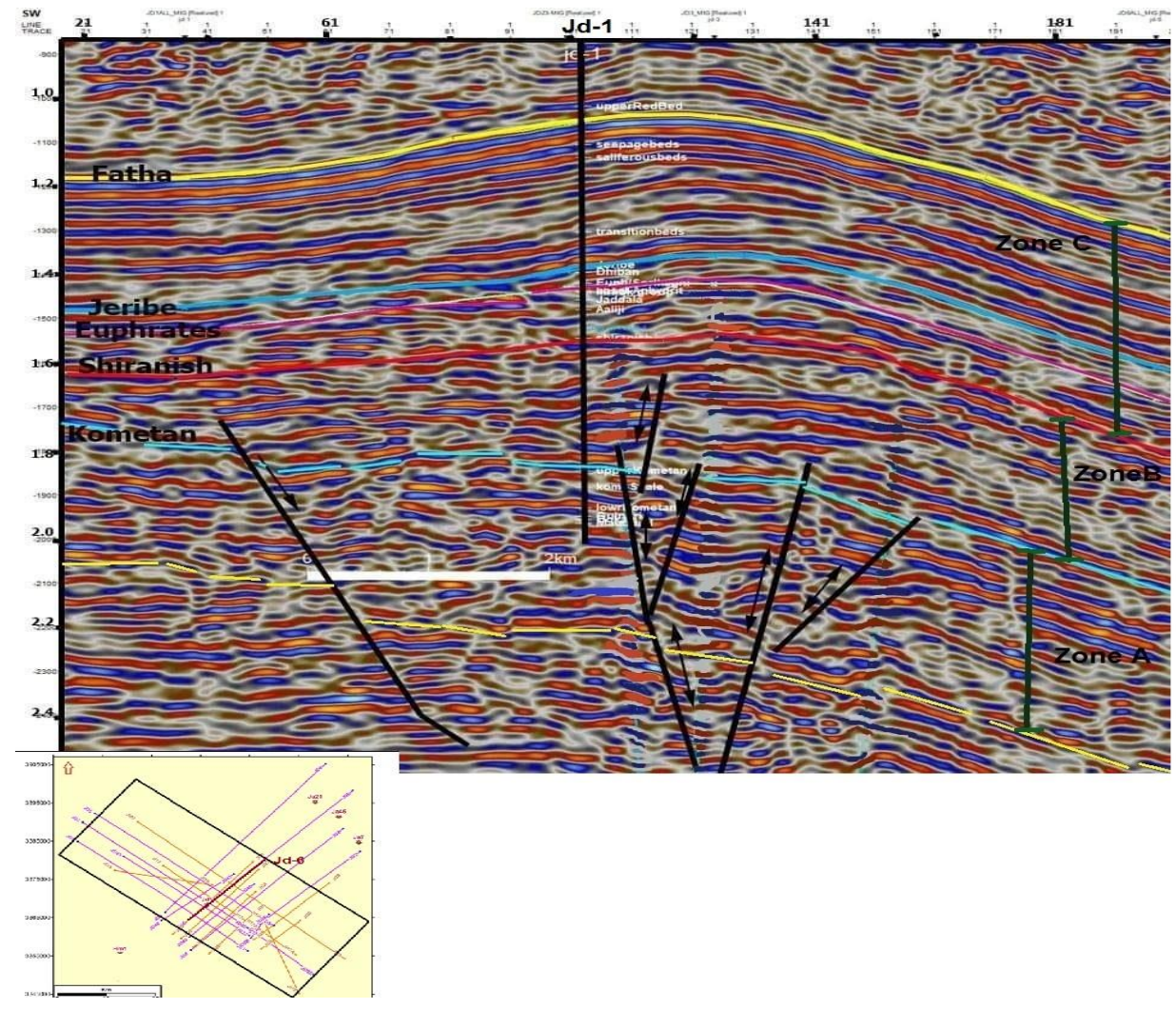

Fig. 3. Seismic sections show inverted faults and the development of Judaida structure during Cretaceous and Tertiary periods in the area

\subsection{Classification of Fold}

Jahangir, (2007), classify the folds by using the certain geometric parameters (Fig.4).

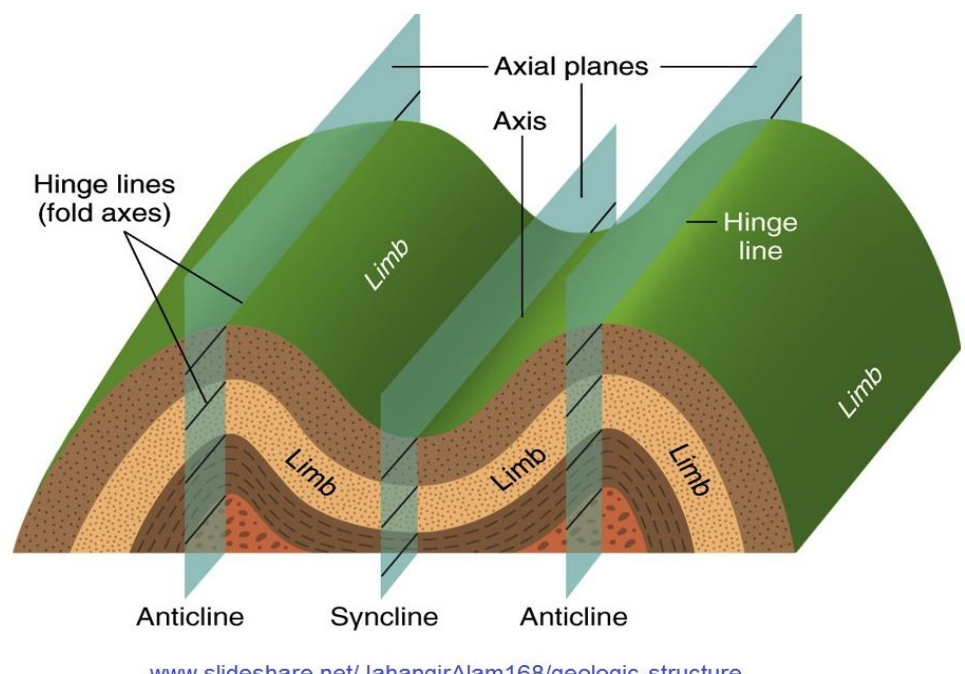

Fig.4. The geometric parameters of a fold (Jahangir A. 2017) 
For the purpose of carrying out this classification of the geometric analysis is needed to make three structural contour maps (Fatha Formation, Jeribe Formation, and Euphrates Formation), (Figs. 5, 6, and 7) and correlation cross section. According to two cross sections, dip section (A - $\left.\mathrm{A}^{-}\right)$, strike section (B $\mathrm{B}^{-}$) was constructed (Figs.8 and 9).

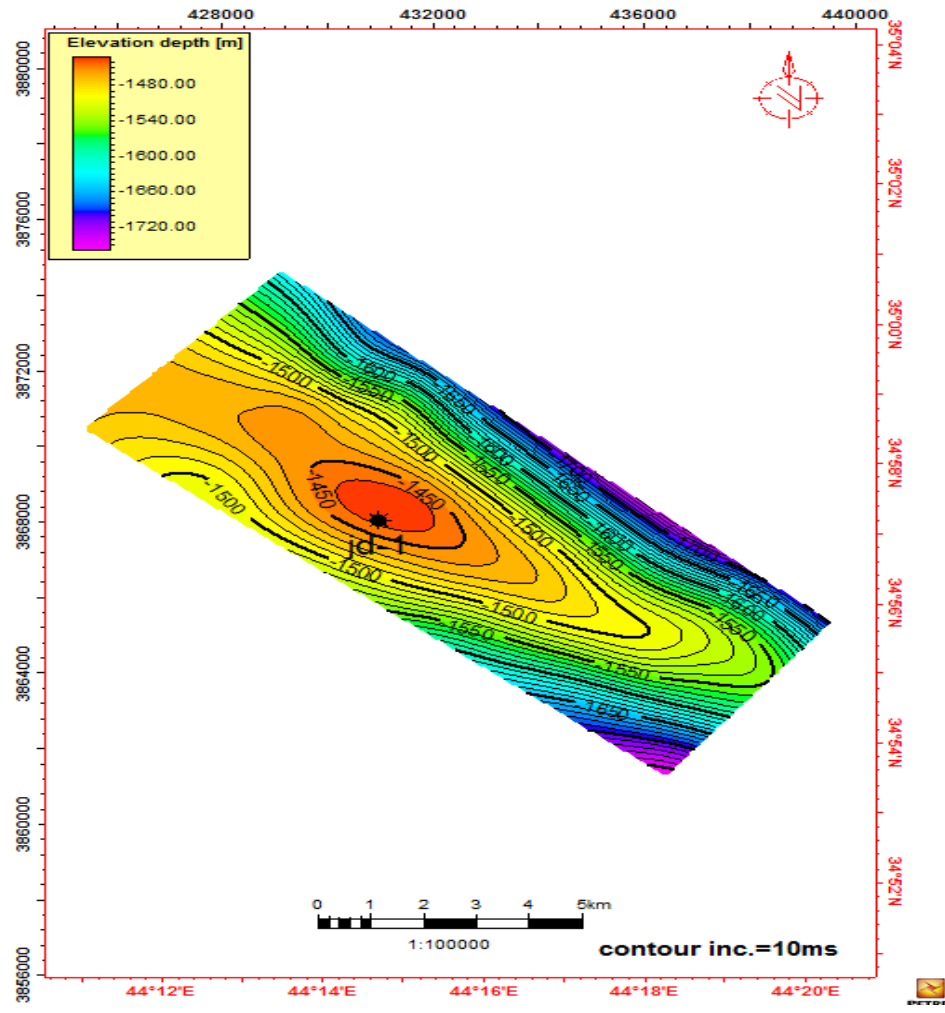

Fig. 5. Depth contour map of the Fatha Formation

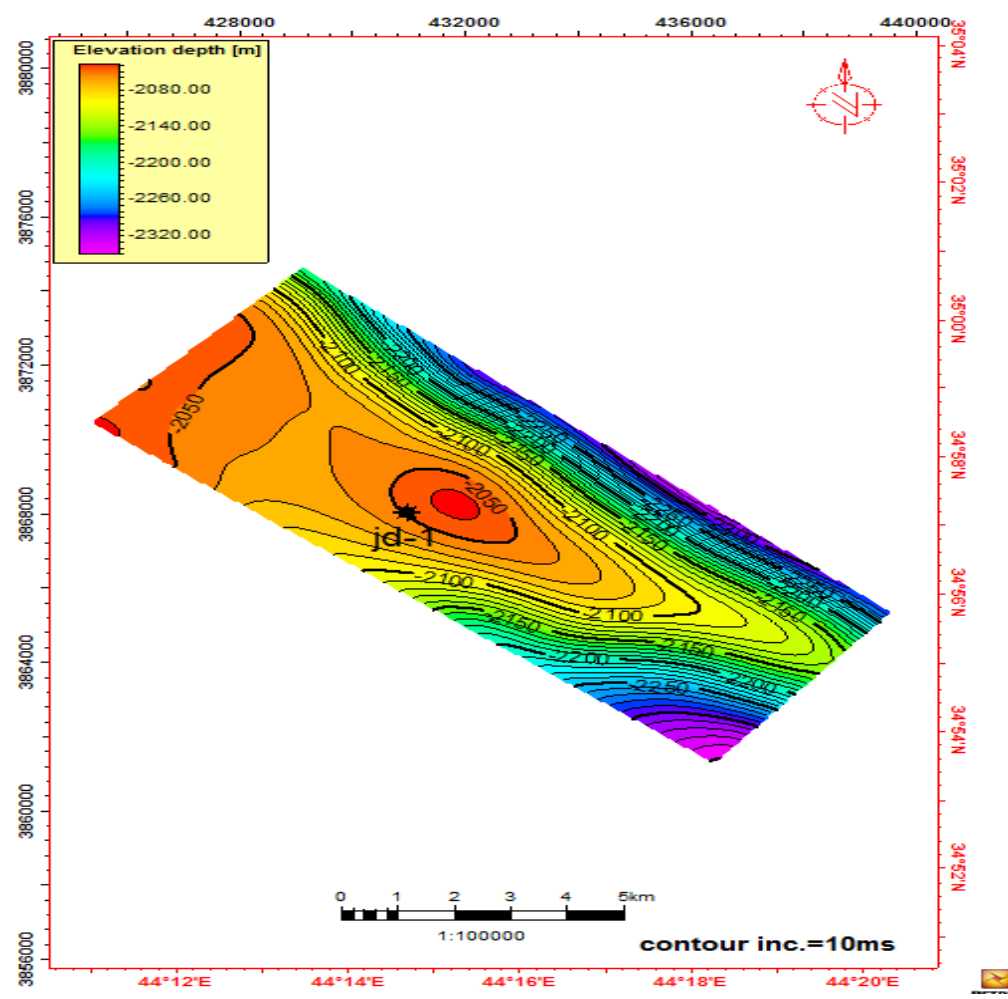

Fig. 6. Depth contour map of the Jeribe Formation. 


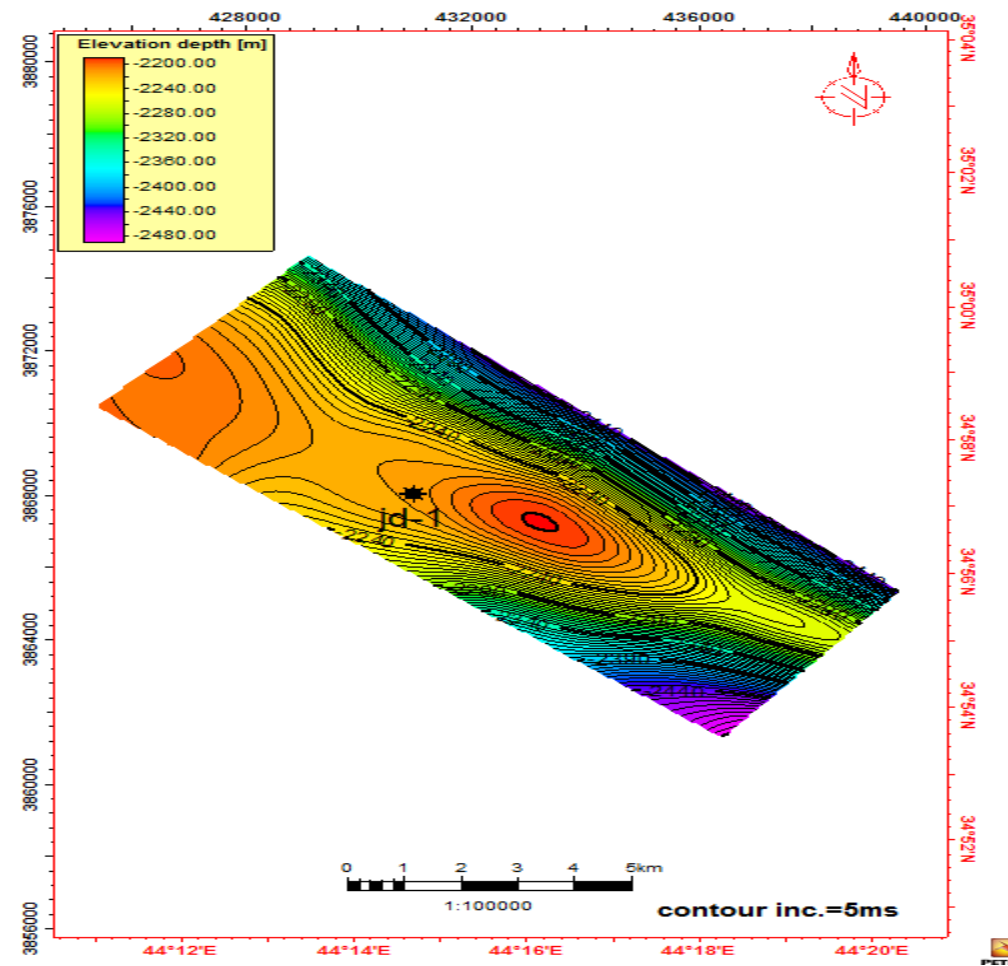

Fig. 7. Depth contour map of Euphrates Formation

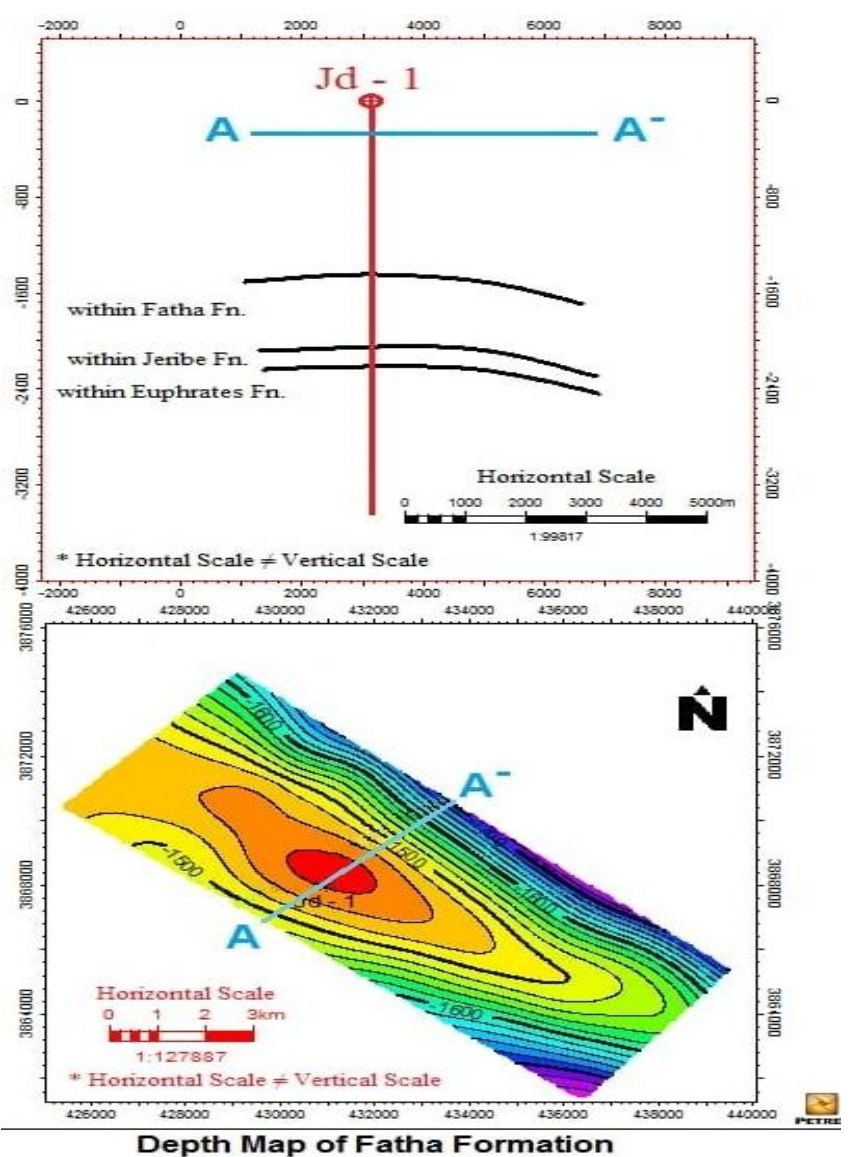

Fig. 8. Correlation Cross Section, Dip sections $\left(A-A^{-}\right)$ 

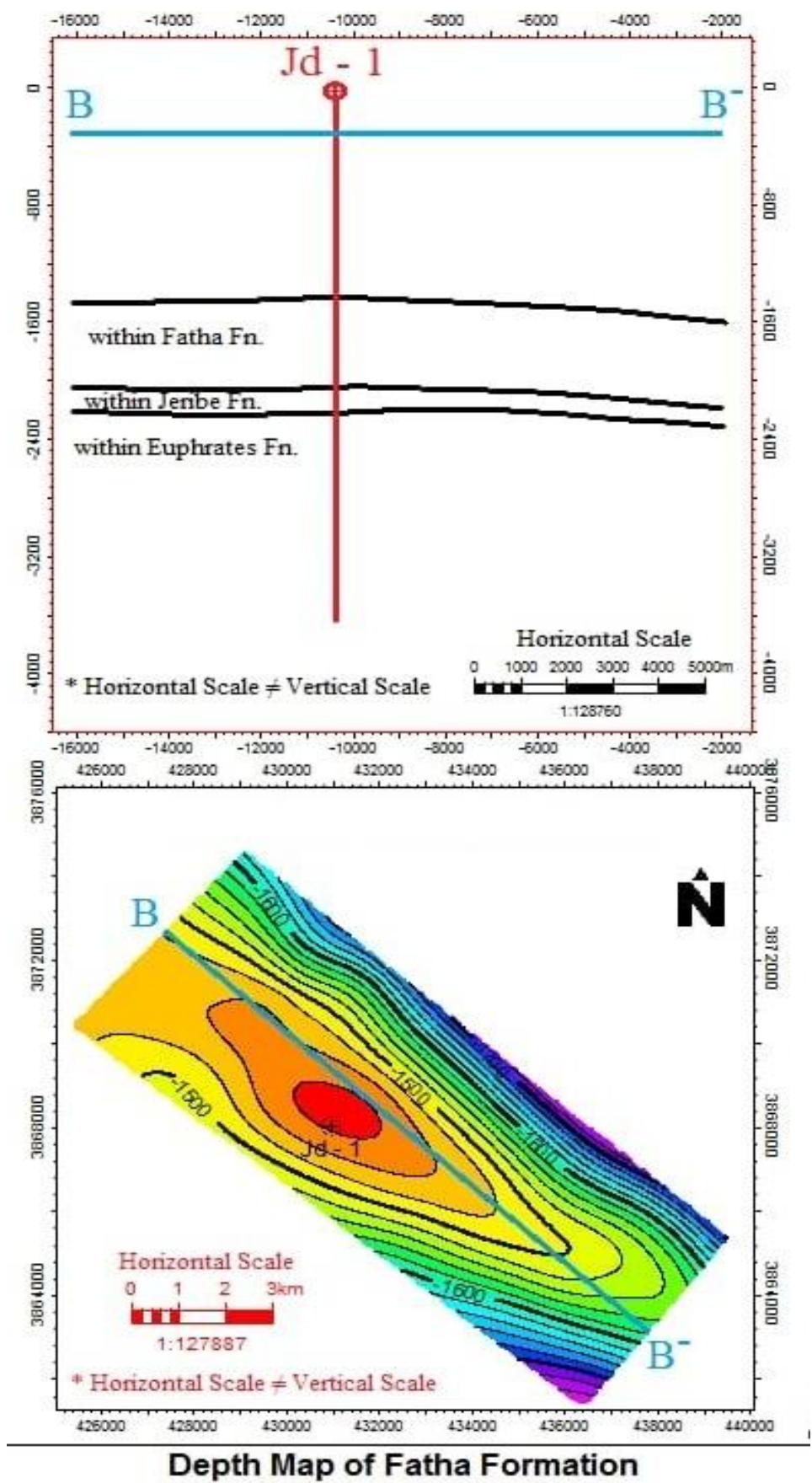

Fig.9. Correlation strike section (B - $\mathrm{B}^{-}$)

To implement this classification, we need to find dip and dip direction and plunge of the hinge line from the structure contour maps of Judaida structure (Table 1).

Table 1. Dip and dip direction and plunge of the hinge line of the Judaida structure

\begin{tabular}{lcccc}
\hline Formation & Dip direction \& dip amount & \multicolumn{2}{c}{ Plunge of the hinge line } \\
\hline & NE limb & SW limb & NW plunge & SE plunge \\
Fatha & $35 / 14.43^{\circ}$ & $215 / 6.9^{\circ}$ & $3.2^{\circ}$ & $4.82^{\circ}$ \\
Jeribe & $35 / 19.41^{\circ}$ & $215 / 7.9^{\circ}$ & $3.2^{\circ}$ & $3.82^{\circ}$ \\
Euphrates & $35 / 19.1^{\circ}$ & $215 / 7.9^{\circ}$ & $3.6^{\circ}$ & $4.12^{\circ}$ \\
\hline
\end{tabular}




\subsubsection{Fold facing}

Park, (1997) classify the fold depending on facing as shown into 1) Antiform; 2) Synform; and 3) Neutral fold (Fig.10)

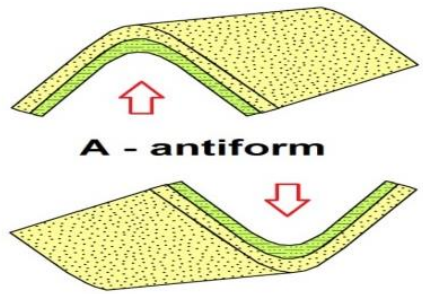

B - synform

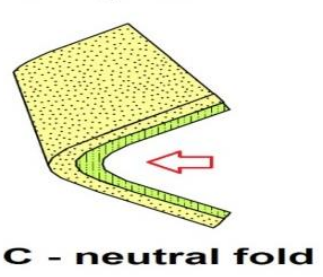

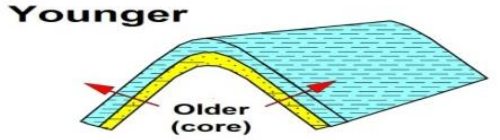

D

Older

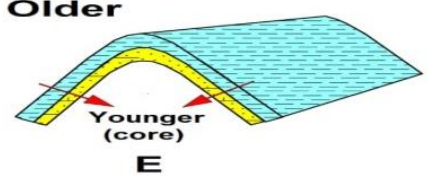

Fig. 10. Classification of folds based on facing of the Park, (1997); According to Park, 1997, the cross section of the Judaida Structure provides an anticline structure (Figs.8, and 9).

\subsubsection{Based on fold dimensions}

Jaroszewski, (1984) classify the fold based on the ratio between the lengths to width of the folds relative to same layer boundary; it has three types:

- Linear fold $\quad \mathrm{L} / \mathrm{W}>5$

- Brachy fold $5>\mathrm{L} / \mathrm{W}>2$

- Domes and basins fold $\mathrm{L} / \mathrm{W}<2$

The axial length and maximum width measured from the contour maps of the Fatha Formation map (Fig. 5) and the Euphrates Formation map (Fig. 7), as shown in Table 2, That indicates Judaida structure belongs to Brachy Fold.

Table 2. The Judaida Structure dimensions

\begin{tabular}{lcccc}
\hline Formation & Contour no. & Length axial (m) & Width axial (m) & Ratio (L / W) \\
\hline Fatha & 1470 & 5420 & 2000 & 2.71 \\
Euphrates & 2140 & 5416 & 1875 & 2.9 \\
\hline
\end{tabular}

\subsubsection{Fold shape in profile plane}

Van Der Pluijm and Marshak, 2004 defined the profile plane of a fold as the plane taken perpendicular to the hinge line. It involves specification of:

- The inter limb angle

Fleuty, 1964 defined the angle made by the limbs of a fold as the fold inter limb angle. The data in Table 1, used in the Georient Software to determine the dip of the axial surface of the fold and to find the interlimb angle (Figs. 11, 12, and 13). And the result in Table 3. Judaida Structure is gentle fold depending on interlimb angle.

- Fold attitudes

A. Dip of axial surface

Van Der Pluijm and Marshak, (2004) classify the fold based on dip of the Axial Surface into three types, as shown in Table 4. 


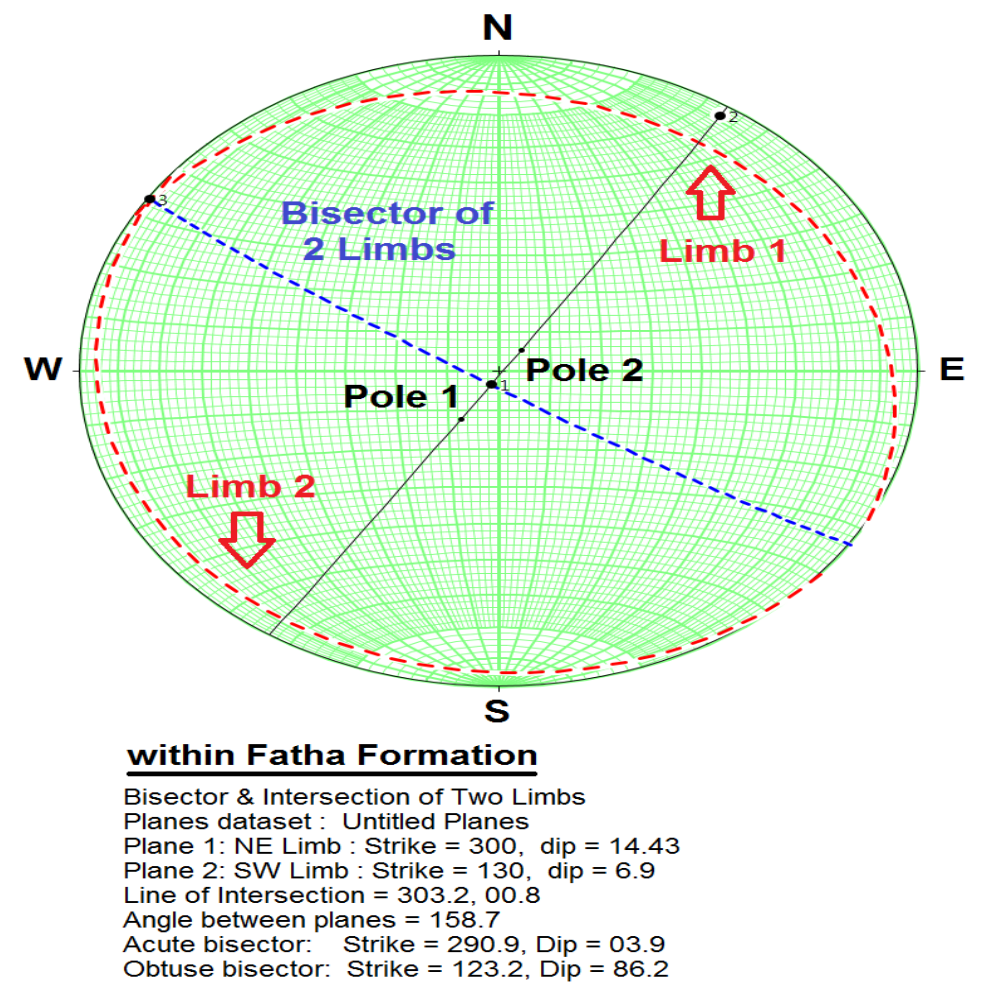

Fig. 11. Stereographic projection of the Judaida Structure within the Fatha Formation

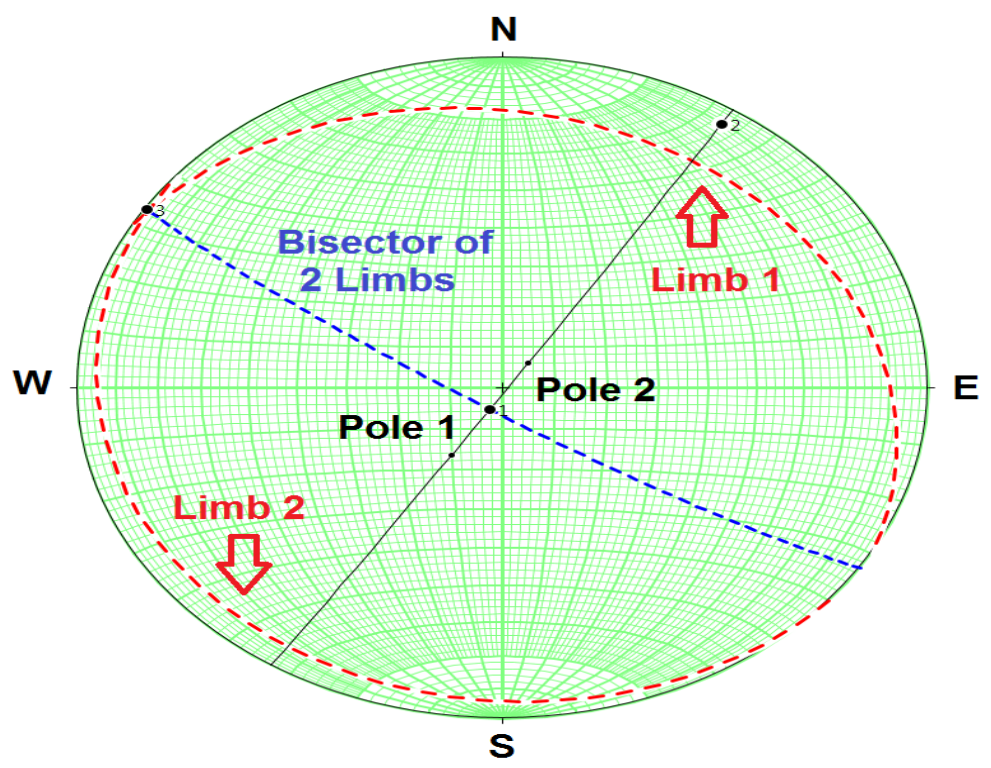

within Jeribe Formation

Bisector \& Intersection of Two Limbs

Planes dataset: Untitled Planes

Plane 1: NE Limb: Strike $=300$, dip $=19.41$

Plane 2: SW Limb : Strike $=130$, dip $=7.9$

Line of Intersection $=302.8,01.0$

Angle between planes $=152.8$

Acute bisector: Strike $=293.1$, Dip $=05.9$

Obtuse bisector: Strike $=122.9$, Dip $=84.2$

Fig. 12. Stereographic projection of the Judaida Structure within the Jeribe Formation 


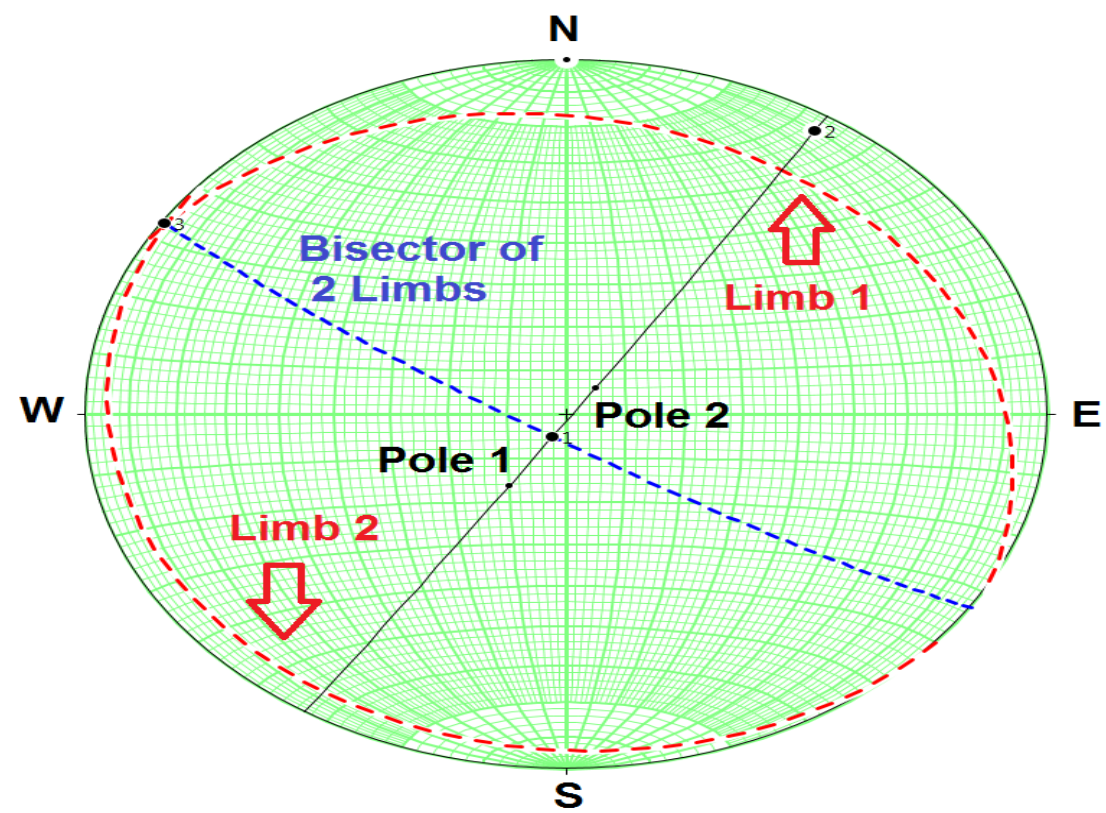

\section{within Euphrates Formation}

$$
\begin{aligned}
& \text { Bisector \& Intersection of Two Limbs } \\
& \text { Planes dataset: Untitled Planes } \\
& \text { Plane 1: NE Limb: Strike }=300, \text { dip }=19.1 \\
& \text { Plane } 2: \text { SE Limb : Strike }=130 \text {, dip }=7.9 \\
& \text { Line of Intersection }=302.9,01.0 \\
& \text { Angle between planes }=153.1 \\
& \text { Acute bisector: Strike }=292.9 \text {, Dip }=05.7 \\
& \text { Obtuse bisector: Strike }=123.0, \text { Dip }=84.4
\end{aligned}
$$

Fig. 13. Stereographic projection of the Judaida Structure within the Euphrates Formation

Table 3. Dip of the axial surface and the interlimb angle of the fold.

\begin{tabular}{lcc}
\hline Formation & Bearing and dip amount of the axial surface & The interlimb angle \\
\hline Fatha & $123.2 / 86.2^{\circ}$ & $158.7^{\circ}$ \\
Jeribe & $122.9 / 84.2^{\circ}$ & $152.8^{\circ}$ \\
Euphrates & $123.0 / 84.4^{\circ}$ & $153.1^{\circ}$ \\
\hline
\end{tabular}

Table 4. Classification of the folds based on the dip of axial surface

\begin{tabular}{lc}
\hline Type of fold & Dip of axial surface \\
\hline Recumbent & $0^{\circ}-10^{\circ}$ \\
Inclined & $10^{\circ}-70^{\circ}$ \\
Upright & $70^{\circ}-90^{\circ}$ \\
\hline
\end{tabular}

Judaida anticline is upright based on the displacement axial surface.

B. Plunge of hinge line

Van Der Pluijm and Marshak, (2004) classify the fold based on the plunge of hinge line into five types, as shown in Table 5 .

Table 5. Classification of the based on the plunge of hinge line

\begin{tabular}{lc}
\hline Type of fold & Plunge of hinge line \\
\hline Horizontal & $0^{\circ}-10^{\circ}$ \\
Shallow & $10^{\circ}-30^{\circ}$ \\
Intermediate & $30^{\circ}-60^{\circ}$ \\
Steep & $60^{\circ}-80^{\circ}$ \\
Vertical & $80^{\circ}-90^{\circ}$ \\
\hline
\end{tabular}


Judaida anticline is horizontal fold depending on the plunge of hinge line.

C. Symmetry of fold

Barnes and Lisle, (2004) used the relationship between length of limbs to explain the symmetry. Asymmetrical folds usually have limbs of unequal length. The Northeastern limb of fold is longer than the Southeastern limb, (fig.8). Then Judaida Structure is asymmetrical Fold.

\section{Conclusions}

- Three depth contour maps, which represented the top of reflectors (Fat'ha, Jeribe and Euphrates formations respectively were constructed and exploited to illustrate the structural image of the Judaida area. In general, the structure has a general trend in the northwest-southeast direction, all of the depth maps for the three reflectors show a structural closure in the middle of the study area.

- The Judaida Structure is represented an asymmetrical longitudinal anticline, brachy, gentle and upright Fold.

- Normal faults it affected the Jurassic, Early Cretaceous, and part of Late Cretaceous age. Because of late Pliocene compression resulted in folding and reverse faulting of the all sequence and inversion of movement along some of the pre-existing normal faults. The resulted faults are called inverted faults and they are presented by two opposite (arrows) directions of displacements.

\section{Acknowledgements}

The authors would like to express their gratitude to the University of Baghdad, Baghdad, Iraq, for their support in completing this work. Also, we would like to thank Oil Exploration Company, the Department of Geology, College of Science, University of Baghdad for their efforts, which have helped to improve the quality of this work. The authors are very grateful to the reviewers, Editor in Chief Prof. Dr. Salih M. Awadh, the Secretary of Journal Mr. Samir R. Hijab, and the Technical Editors for their great efforts and valuable comments.

\section{References}

Abdullah, A, M., Al-Rahim, A, M., and Jassem, K, A., 2021. 2D seismic reflection and interpretation study of the Khan Al- Baghdadi area within the Paleozoic Era (western Iraq). Iraqi Journal of science, 62 (8), 2627-2639.

Ahmad, M. M., 2018. Study of structural style of Ratawi field, southern Iraq, College of science, university of Baghdad, Baghdad, Iraq. 116 pp.

Almayahi, D. S., 2004. Structural and Tectonic Study of Hemrin- Makhul Folded Belt (North Eastern Iraq). Unpublished Master Thesis, Science College, University of Basrah, 89pp.

Al-Ridha, N., and Al-Khafaji, H. , 2019. Stratigraphic and structural study of Khlesia Region using 2D seismic data, North Western Iraq. Iraqi Journal of Science, 60 (2), 277-289.

Aqrawi, A. A. M., Goff J. C., Horbury A. D., and Sadooni, F. N, 2010. The Petroleum Geology of Iraq: Beaconsfield, United Kingdom, Scientific press Ltd., 424 pp.

Barnes, J. W. and Lisle R. j., 2004. Basic Geological Mapping. $4^{\text {th }}$. Ed. Jone Whily Son Ltd. UK. P345.

Dobrin, M., 1976. Introduction to geophysical prospecting, $3^{\text {rd }}$ ed., McGraw Hill. Int. Co., International Student Edition 386 pp.

Jahangir, A., 2017. Geologic structure, fold, fault \& unconformity.

Jaroszewski, W., 1984.Fault and fold tectonic, Ellis Horwood Ltd. England, 565 pp.

Jassim, S. Z., and Goff, J. C., 2006. Geology of Iraq. Dolin, Prague and Moravian Museum, Zelnytrh 6, Brno, Czech Republic, 30 pp.

Khan, M. J., Umar, M., Khan, M., and Das, A., 2019. 2D Seismic interpretation to understand the structural geometry of Cretaceous sand packages, Jabo Field, Pakistan. The Nucleus, 56, (2), 78-85. 
Marouf, N. Z., and AL-Kubaisi, M. Sh., 2005. Inversion and folding of the southern un-elevated folded belt in North Iraq. Iraqi Geological Journal, 34-38,1.

Park, R. G., 1997. Foundation of structural geology, The Alden Press, Osney Mead, Oxford, $3^{\text {rd }}$ edition. U. K. 202 pp.

United Nation, 2014. Iraq Administered Map, Department of field support, Cartographic section, Map No. 3835 Rev.6.

Van Der Pluijm, B. A. and Marshak S., 2004. Earth structure an introduction to structural geology and tectonic "McGraw - Hill, p. 673.

Zahra, H., and Nakhla, A., 2016. Structural interpretation of seismic data of Abu Rudeis-Sidri area, Northern Central Gulf of Suez, Egypt. Journal of Astronomy and Geophysics, 5 (2), 435-450. 